\section{Australian Journal of \\ Crop Science}

AJCS

ISSN:1835-2707

\title{
Designing of soil quality and climate assessment tool for sustainable production of signalgrass (Brachiaria brizantha) silvopasture system in mountain ecosystems
}

\author{
Priyono Suryanto* ${ }^{1}$, Eny Faridah ${ }^{1}$, Ananto Triyogo ${ }^{1}$, Dody Kastono ${ }^{2}$, Bambang Suwignyo ${ }^{3}$, Aprilia lke \\ Nurmalasari ${ }^{4}$, Taufan Alam ${ }^{2}$
}

${ }^{1}$ Department of Silviculture, Universitas Gadjah Mada, Yogyakarta, Indonesia

${ }^{2}$ Department of Agronomy, Universitas Gadjah Mada, Yogyakarta, Indonesia

${ }^{3}$ Department of Animal Nutrition and Feed Science, Universitas Gadjah Mada, Yogyakarta, Indonesia

${ }^{4}$ Department of Agrotechnology, Universitas Sebelas Maret, Surakarta, Indonesia

\section{*Corresponding author: psuryanto@ugm.ac.id}

Abstract

\begin{abstract}
Evironmental indicators are the elements required to plan sustainable forest management practices. This assessment was carried out based on indicators that are sensitive to management and changes in the soil, climate, and associated functions. This study aims at determining soil quality and climate that affect the production of signalgrass silvopasture system in mountain ecosystems. The survey-based study was conducted during dry and wet seasons in 2017-2018. We used stratified random sampling method. Stratification was based on site (agroforestry phase) and environment (season and year). Site nested on environment. Agroforestry phases consisted of initial phase ( $<50 \%$ of the shade intensity of the sun), intermediate phase $(50-70 \%$ of the shade intensity of the sun), and advanced phase ( $>70 \%$ of the shade intensity of the sun). Seasons were divided into two, dry season (rainfall $<60$ $\mathrm{mm} \cdot \mathrm{month}^{-1}$ ) and wet season (rainfall $>100 \mathrm{~mm} \cdot \mathrm{month}^{-1}$ ) and years were limited from 2017 to 2018 . The observation was conducted on 30 environmental parameters and signalgrass productions. The data was analyzed using linear mixed models, analysis of variance (ANOVA), structural equation modelling (SEM), and stepwise regression. The study results indicate that the highest signalgrass production at the initial agroforestry phase was 4.50 tons. ha ${ }^{-1}$. There is a very significant decrease in signalgrass production at the intermediate agroforestry phase by $36.64 \%$ and at the advanced agroforestry phase by $280.80 \%$, compared to the initial agroforestry phase. The signalgrass production was increased very significantly influenced by the increase in cation exchange capacity (CEC), soil organic carbon (SOC), air temperature (Tair), and wind speed $\left(\mathrm{U}_{2}\right)$. In addition, it was also significantly influenced by available nitrate $\left(\mathrm{NO}_{3}{ }^{-}\right)$. Signalgrass production can be improved by the assessment tools by improving $\mathrm{CEC}, \mathrm{NO}_{3}{ }^{-}$, $\mathrm{SOC}, \mathrm{U}_{2}$, and Tair with routine organic matters application and annual pruning.
\end{abstract}

Keywords: climate; mountain ecosystems; signalgrass; silvopasture system; soil quality.

Abbreviations: Cly_\% clay, San_\% sand, Sil_\% silt, BD_bulk density; ASM_available soil moisture; Perm_permeability, $\mathrm{pH} \_\mathrm{pH} \mathrm{H}_{2} \mathrm{O}$; CEC_cation exchange capacity; EC_electrical conductivity; SOC_soil organic carbon; $\mathrm{N}_{-}$available nitrogen; $\mathrm{NO}_{3}{ }_{3}^{-}$available nitrate; $\mathrm{NH}_{4+}$ available ammonium; K_available potassium; $\mathrm{Na}$ _available sodium; Ca_available calcium; Mg_available magnesium; Fe_available iron; $\mathrm{Mn} \_$available manganese; $\mathrm{Cu}$ _available copper; $\mathrm{Zn}$ _available zinc; Bac_amounts of bacterium; Fu_amounts of fungi; Res_total respiration; Tair_air temperature; Tsoil_soil temperature; $\mathrm{RH}_{-}$relative humidity; $\mathrm{U}_{2} \_$wind speed; Rs_solar radiation; SEM_structural equation modelling.

\section{Introduction}

Mountain ecosystems provide various needs for those who live in the mountain and those who do not live in the mountain. In addition, mountain ecosystems play important roles in biodiversity conservation (Chester et al., 2013). Mount of Merapi in Central Java, Indonesia is categorized as one of the world's active and dangerous volcanos (Gertisser et al., 2012). Characteristic of agriculture developing on the southern slopes of Merapi Mount is called agroforestry systems that specifically use silvopasture approach (Suryanto et al., 2011). Silvopasture practice is an agroforestry technology combining trees, forage, and shrubs with livestock operation. Many researchers have noted that silvopasture practices provide environmental benefits, such as water quality improvement, soil conservation, carbon sequestration, wildlife habitat protection, and aesthetics (Clason and Sharrow, 2000; Garrett et al., 2000; Kurtz, 2000; Alavalapati and Nair, 2001). The silvopasture pattern on the southern slope of Merapi Mount is generally a mixture of sengon (Falcataria molucana), Acacia decurren, and signalgrass (Brachiaria brizantha). Signalgrass is a tropical and sub-tropical grass widely cultivated for forage. Signalgrass widely spreads in South America, Australia, Indonesia, Vanuatu, and Malaysia (Low, 2015). The type of grass is widely developed in silvopasture systems. It is an 
adaptation to a varied range of soil types and environments (Chung et al., 2018). The determinant factors of the success in signalgrass cultivation are climate and soil quality. Climate and soil quality affect plant growth and yields. Identification of climate and soil quality assists to determine appropriate management for sustainable crop production (Neenu et al., 2013). Soil quality is an assessment of how the soil functions and a preparation for the future (Makalew, 2011). Soil quality is a basis for improving sustainable land use management (MacGrath and Zhang, 2003; Qi et al., 2009). It is an adaptation to varied range of soil types and environments. Soil quality assesment is an important instrument for helping the farmers to plan sustainable forest management practices. In addition, soil quality assesment can make efficient time, energy, and cost (Glover et al., 2000; Rossi et al., 2009). Soil quality cannot be directly assessed in case of need of soil quality indicators (Makalew, 2011). Chemical, physical, and biological properties of integrated soil quality are dynamic concepts sensitive to soil management practices (Bilgili et al., 2017). Parameters of physical, chemical and biological properties of the soil produce soil quality measurements called minimum data sets (MDS) (Makalew, 2011). Several studies relating to soil quality assessment indicate different land evaluation parameters. MDS is very dependent on the diversity of locations, scale, different land management, and research objectives (Rousseau, 2012). Suryanto et al. (2017) conducted a study relating to soil quality assessment at Menoreh Mountain Area in Special Province of Yogyakarta, Indonesia for sustainable clove, cacao, and cardamom productivity in agroforstry system. The study results indicate that the dry weight of clove flowers was affected by the \% silt. The dry weight of cocoa beans was influenced by CEC, $\mathrm{Ca}$, and $\mathrm{Na}$, while the dry weight of cardamom bulbs was influenced by $\mathrm{Ca}$.

Several studies relating to soil quality assesment have been conducted but most of them only assessed soil quality without considering climate factors. The study aims at determining soil quality and climate that affect the production of signalgrass silvopasture system in mountain ecosystems. The study exerts to combine soil quality and climate assesment; thereby, giving more comprehensive outputs. The study results can expectedly inform the farmers, researchers, and policy makers on how to improve the production of signalgrass silvopasture system in mountain ecosystems.

\section{Results and Discussion}

\section{Characteristic of locations}

The altitude of the study site varied from 700 to 900 metres above sea level. The air temperature ranged from $24-27^{\circ} \mathrm{C}$. The $\mathrm{RH}$ ranged from $70-90 \%$ and the total rainfall ranged from 2,000-2,200 mm.year ${ }^{-1}$. Average $U_{2}$ was $54.20 \mathrm{~km}$.hour ${ }^{-}$ ${ }^{1}$ and Rs was $5.34 \mathrm{~mm} \cdot \mathrm{day}^{-1}$. Therefore, the climate at the study site is categorized as tropical monsoon climate (Beck et al., 2018).

The study site had an udic moisture regime. It was a soil regime predominantly moist regime for humid climate land with well distributed rainfall. In most years, the soil was dry (in any part of soil moisture control section) for $<90$ cumulative days (Soil Survey Staff, 2014).

\section{Signalgrass production at the agroforestry phase}

Least square result means a linear mixed model indicating a very significant difference of signalgrass production $(P<$ $0.01)$ at the agroforestry phase. The highest signalgrass production at the initial agroforestry phase was 4.50 tons.ha ${ }^{1}$ followed by the intermediate agroforesty phase by 3.29 tons. ha ${ }^{-1}$ and 1.18 tons.ha ${ }^{-1}$. A very significant decrease in signalgrass production at the intermediate agroforestry phase was $36.64 \%$ and at the advanced agroforestry phase by $280.80 \%$ compared to the initial agroforestry phase (Fig 1 and Table 1).

Signalgrass production potential was 10.10 tons.ha ${ }^{-1}$. Study results indicate that signalgrass production at the study site is below the potential results; thereby, requires an assessment to improve signalgrass production from soil quality and climate factors.

\section{Selection of key environment indicators for sustainable} production of signalgrass

The results of ANOVA on climate and soil quality indicators indicate significant differences $(p<0.05)$ and coefficient variances of $\angle 40 \%$ of Sil, San, BD, ASM, Perm, pH, SOC, CEC, $\mathrm{EC}, \mathrm{N}, \mathrm{NO}_{3}{ }^{-}, \mathrm{NH}_{4}{ }^{+}, \mathrm{P}, \mathrm{K}, \mathrm{Na}, \mathrm{Ca}, \mathrm{Mg}, \mathrm{Fe}, \mathrm{Mn}, \mathrm{Cu}, \mathrm{Zn}, \mathrm{Bac}, \mathrm{Fu}$, Res, T-air, T-soil, $\mathrm{RH}, \mathrm{U}_{2}$, and Rs (Table 2). The parameters were maintained for continuous SEM analysis after ANOVA. SEM analysis results indicate that parameters not indicating a significant difference in soil physical property was permeability $(p<0.295)$. Soil chemical property was $\mathrm{Cu}$ $(p<0.399)$, and soil biological property was FU $(p<0.095)$ (Fig 2). The parameters not indicating significant differences were not used for stepwise regression analysis.

The results of stepwise regression indicated that the increase in signalgrass production was very significantly influenced by the increase in CEC, SOC, Tair, and $U_{2}$. In addition, it was also significantly influenced by $\mathrm{NO}_{3}{ }^{-}$. The stepwise regression equation was $\mathrm{Y}=-75.460 * *+0.174 \mathrm{U}_{2}$ $* *+1.531 \mathrm{CEC}^{* *}+0.005 \mathrm{NO}_{3}{ }^{*}+1.070$ Tair $* *+3.377 \mathrm{SOC}$ $* *\left(\mathrm{R}^{2}=0.970 * *\right)$.

\section{Assessment tools for sustainable production of signalgrass}

The improvement of soil quality and climate highly improved signalgrass production. Soil quality affecting signalgrass production was $\mathrm{CEC}$, SOC, and $\mathrm{NO}_{3}{ }^{-}$contents. Proper cultivation management was required to improve soil quality particularly $\mathrm{CEC}, \mathrm{SOC}$, and $\mathrm{NO}_{3}^{-}$contents in the soil. The assesment tools for land management to improve soil quality were organic matters application and nitrogen fertilization.

Climate factors such as $\mathrm{U}_{2}$ and Tair highly influenced signalgrass production. The increase in $\mathrm{U}_{2}$ and Tair highly improved signalgrass production. Land management can be improved by the assessment tools by improving climate factors and making annual pruning of the trees that shade the signalgrass. It can expectedly improve micro climate under the stands for more optimum growth of signalgrass. 
Table 1. The least squares means for the signalgrass production in different agroforestry phase.

\begin{tabular}{lccccc}
\hline Agroforestry Phase & $\begin{array}{c}\text {-Agroforestry } \\
\text { Phase }\end{array}$ & Difference & Std Error & t Ratio & \multirow{2}{*}{ Prob $>|\mathrm{t}|$} \\
\hline Advanced & Initial & -3.31583 & 0.3944677 & $-8.41^{* *}$ & $<.0001$ \\
Advanced & Intermediate & -2.11000 & 0.3944677 & $-5.35^{* *}$ & 0.0005 \\
Initial & Intermediate & 1.20583 & 0.3944677 & $3.06^{*}$ & 0.0135 \\
\hline
\end{tabular}

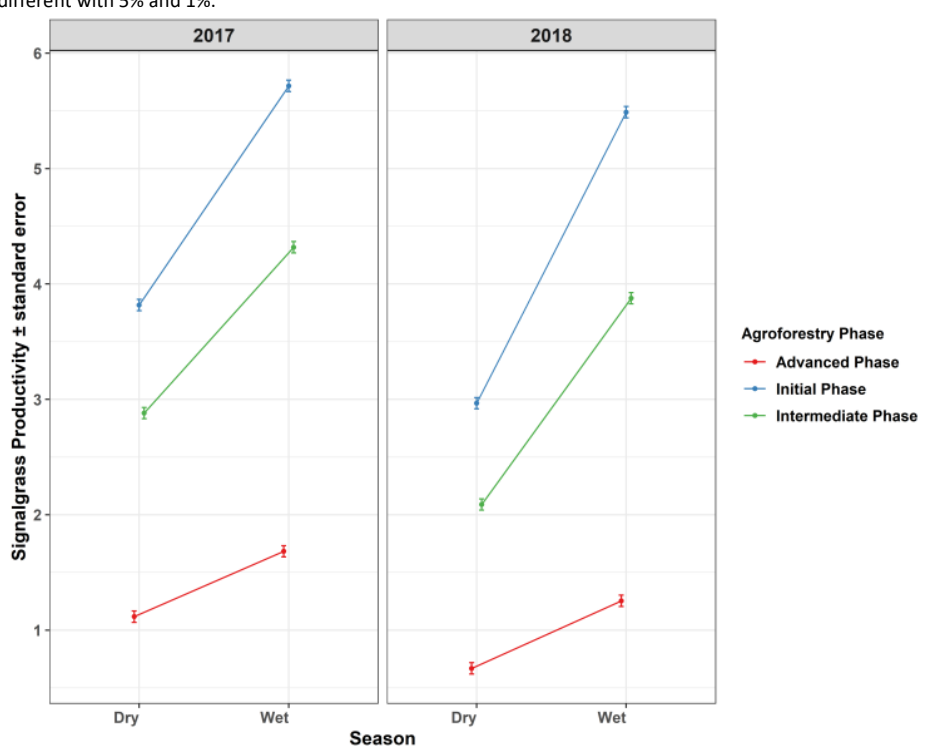

Fig 1. The signalgrass production (tons. ha ${ }^{-1}$ ) affected by agroforestry phase.

Table 2. The soil quality and climate factors affected by agroforestry phase.

\begin{tabular}{|c|c|c|c|c|c|}
\hline \multirow{2}{*}{$\begin{array}{l}\text { Soil Quality and Climate } \\
\text { Variable }\end{array}$} & \multirow{2}{*}{ Parameter } & \multicolumn{3}{|c|}{ Mean squares treatment ANOVA } & \multirow{2}{*}{$\begin{array}{l}C V \\
(\%)\end{array}$} \\
\hline & & Error & Treatment & & \\
\hline Soil & $\%$ Clay & 0.178 & 1.249 & $* *$ & 43.79 \\
\hline \multirow[t]{5}{*}{ Physics } & $\%$ Sand & 0.039 & 0.771 & $* *$ & 0.23 \\
\hline & $\%$ Silt & 0.107 & 0.549 & $* *$ & 2.54 \\
\hline & Bulk Density & $2.78 \times 10^{-6}$ & $4.45 \times 10^{-3}$ & $* *$ & 0.16 \\
\hline & Available Soil Moisture & 176.442 & 43442.86 & $* *$ & 3.14 \\
\hline & Permeability & 0.007 & 2.883 & $* *$ & 0.29 \\
\hline \multirow[t]{16}{*}{ Soil Chemistry } & $\mathrm{pH} \mathrm{H}_{2} \mathrm{O}$ & 0.003 & 0.313 & $* *$ & 0.81 \\
\hline & Soil Organic Carbon & $4.58 \times 10^{-4}$ & 0.129 & $* *$ & 1.21 \\
\hline & Cation Exchange Capacity & 0.002 & 0.791 & $* *$ & 0.22 \\
\hline & Electrical Conductivity & $6.90 \times 10^{-5}$ & 0.012 & $* *$ & 0.60 \\
\hline & Nitrogen & 22.643 & 1066.22 & $* *$ & 3.61 \\
\hline & Ammonium & 0.247 & 124.950 & $* *$ & 1.06 \\
\hline & Nitrate & 2.777 & 1960.856 & $* *$ & 1.66 \\
\hline & Phosphorus & 0.012 & 4.127 & $* *$ & 1.53 \\
\hline & Potassium & 0.0004 & 0.091 & $* *$ & 2.46 \\
\hline & Sodium & $5.25 \times 10^{-5}$ & 0.066 & $* *$ & 1.04 \\
\hline & Calcium & $2.89 \times 10^{-5}$ & 4.168 & $* *$ & 0.09 \\
\hline & Magnesium & $7.64 \times 10^{-6}$ & 0.024 & $* *$ & 0.85 \\
\hline & Iron & $2.68 \times 10^{-4}$ & 3.986 & $* *$ & 0.15 \\
\hline & Manganese & 0.003 & 26.998 & ** & 0.19 \\
\hline & Copper & $1.94 \times 10^{-4}$ & 0.602 & $* *$ & 0.56 \\
\hline & Zinc & $3.06 \times 10^{-4}$ & 0.328 & $* *$ & 1.08 \\
\hline Soil & Amounts of Bacterium & $1.56 \times 10^{-3}$ & 5.420 & $* *$ & 1.41 \\
\hline \multirow[t]{2}{*}{ Biology } & Amounts of Fungi & $8.44 \times 10^{-4}$ & 3.879 & $* *$ & 1.52 \\
\hline & Total Respiration & 0.006 & 31.917 & $* *$ & 0.76 \\
\hline \multirow[t]{5}{*}{ Macro and Micro Climate } & Air Temperature & 0.006 & 1.582 & $* *$ & 0.30 \\
\hline & Soil Temperature & 0.050 & 1.853 & $* *$ & 0.81 \\
\hline & Relative Humidity & 0.876 & 67.569 & $* *$ & 1.15 \\
\hline & Wind Speed & 0.768 & 312.30 & $* *$ & 1.62 \\
\hline & Solar Radiation & 0.058 & 16.200 & ** & 4.51 \\
\hline
\end{tabular}




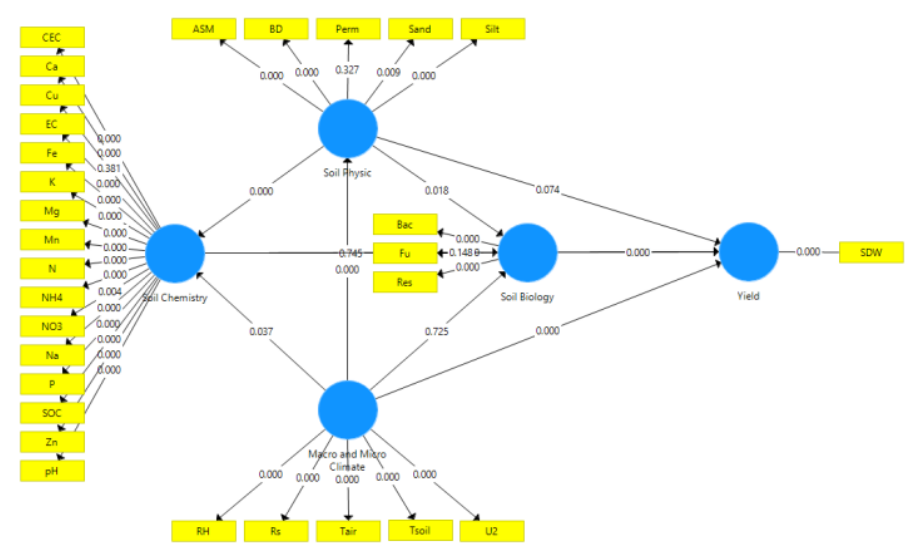

Fig 2. The relationship between soil quality and climate factors towards the signalgrass production.

Table 3. Protocol of measurements for each indicators.

\begin{tabular}{|c|c|c|}
\hline Variable & Protocol & Reference \\
\hline \multicolumn{3}{|l|}{ Physics: } \\
\hline 1. Soil Texture( $\%$ Clay, $\%$ Sand, $\%$ Silt $)$ & Robinson Pipette Method & Aubert et al. (1954) \\
\hline 2. Bulk Density & Ring Sample & Blake and Hartge (1986) \\
\hline 3. Available Soil Moisture & Gravimetric & $\begin{array}{l}\text { Alam (2014); Dwidjopuspito } \\
\text { (1986) }\end{array}$ \\
\hline 4. Permeability & Permeameter & Blake and Hartge (1986) \\
\hline \multicolumn{3}{|l|}{ Chemistry: } \\
\hline 1. $\mathrm{pH} \mathrm{H}_{2} \mathrm{O}$ & pH Meter & Van Reeuwijk (1993) \\
\hline 2. Soil Organic Matters & Walkey and Black & Black (1965) \\
\hline 3. Cation Exchange Capacity & Ammonium Acetate & $\begin{array}{l}\text { Hajek et al. (1972); Van } \\
\text { Reeuwijk (1993) }\end{array}$ \\
\hline 4. Electrical Conductivity & $\mathrm{pH}$ Meter & Richards (1954) \\
\hline $\begin{array}{l}\text { 5. Available Nitrogen, Nitrate, and } \\
\text { Ammonium }\end{array}$ & Devarda's Alloy Method & Stenhom et al. (2009) \\
\hline 6. Available Phosphorus & Olsen (Spectrophotometry) & Olsen et al. (1954) \\
\hline 7. Available Potassium and Sodium & Flame Photometer & Burt (2004); Jones (1984) \\
\hline $\begin{array}{l}\text { 8. Available Calcium, Magnesium, Iron, } \\
\text { Manganese, Copper, and Zinc }\end{array}$ & $\begin{array}{l}\text { Atomic Absorption } \\
\text { Spectrophotometry } \\
\text { (AAS) }\end{array}$ & $\begin{array}{l}\text { Burt (2004); Jones (1984); van } \\
\text { Reeuwijk (1993) }\end{array}$ \\
\hline \multicolumn{3}{|l|}{ Biology: } \\
\hline 1. Amounts of Bacterium & Dilution-Plate & David and Davidson (2014) \\
\hline 2. Amounts of Fungi & Dilution-Plate & David and Davidson (2014) \\
\hline 3. Total Respiration & Dilution-Plate & David and Davidson (2014) \\
\hline
\end{tabular}

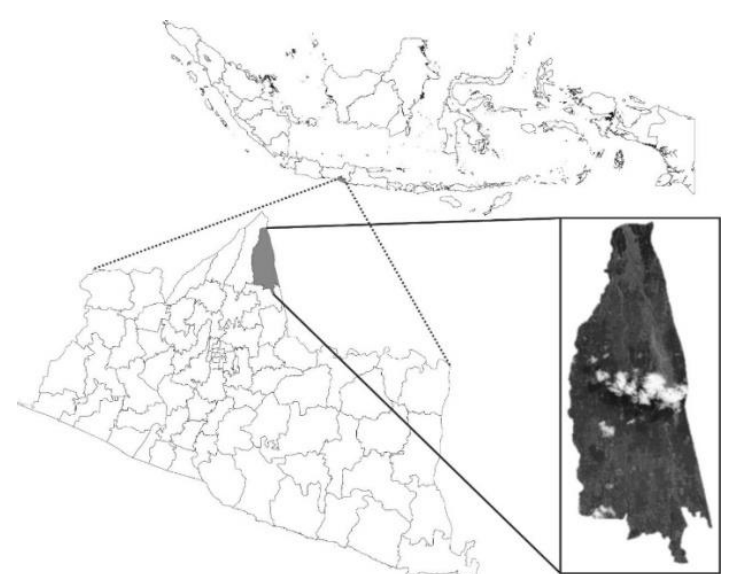

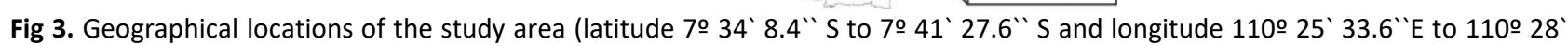
$51.6^{\prime \prime} \mathrm{E}$ 
Plant adaptation to infertile soils was complex and affected by the environment. Consequently, it is difficult to identify and quantify the genetic and physiological mechanisms leading to the adaptation (Cobb et al., 2013). The difference of signalgrass production in each agroforestry phase is resulting from the difference of soil quality and climate. Soil quality or also called soil nutrition is also an important element for the plant growth. Most plant nutrients are absorbed by the roots of the plants from the soil (Khalil et al., 2015).

CEC was the total exchangeable cations, which may hold in the soil by electrostatic forces at a specific $\mathrm{pH}$ level (Bauer and Velde, 2014). The increase in CEC in the soil was very significant to improve signalgrass production. Average CEC value in the study site was $22.74 \%$. It was still moderate. CEC affected soil stability, nutrient availability, soil $\mathrm{pH}$, and soil reaction to fertilizers and other ameliorants, as well as became a buffer against soil acidification (Hazelton and Murphy, 2007). Other studies informed that the increase in CEC positively correlates to the increase in cacao yields with agroforestry system at Menoreh Mountain Area, Indonesia (Suryanto, 2017).

SOC was considered as a key feature in health and crop productivity (Brandão and Canals, 2013; Brady et al., 2015). A very significant SOC content in the soil increased signalgrass production. Average $\mathrm{SOC}$ value in the study site was $1.76 \%$, which is considered low level. SOC was an important element for sustainable land to create safe and healthy production and to recover land fertility and reduce climate change (Timsina, 2018).

$\mathrm{N}$ was an important element required for the growth of plants. Inorganic components of nitrogen (i.e., $\mathrm{NO}_{3}{ }^{-}, \mathrm{NH}_{4}{ }^{+}$, and $\mathrm{NO}_{2}{ }^{-}$) contributed less than $5 \%$ of the total nitrogen in the soil (Brady and Weil, 2008). N availability is a major determinant of ecosystem properties (Boudsocq et al., 2012). Average $\mathrm{NO}_{3}{ }^{-}$value in the study site was $1.49 \mathrm{ppm}$, which was still low. $\mathrm{NO}_{3}{ }^{-}$was an important element that played roles in plant physiological activity. The increase in $\mathrm{NO}_{3}{ }^{-}$content in the soil positively correlated to the increase in nitrate reductase activity (NRA) in the leaves and stem tissues and tanner grass growth (Brachiaria radicans Napper) (Cazzeta and Villela, 2004).

The increase in $\mathrm{U}_{2}$ and T-air highly improved signalgrass production. Fundamental wind and temperature played roles in ecosystems and water cycles since they highly affected the evacuation of rates (Dinpashoh et al., 2011). Average $U_{2}$ in the study site was $54.20 \mathrm{~km} /$ hour $^{-1}$. There is a perception that the increase in wind speed increases the transpiration from the plant leaves. However, it proves that the increase in carbon dioxide enhancement speed $\left(\mathrm{CO}_{2}\right)$ with reducing transpiration is resulting from more efficient cooling (under high solar radiation loads) (McVicar et al., 2012).

Our theoretical and experimental studies proved that leaf water use efficiency (WUE, carbon uptake per transpired water) usually increases with the increase in wind velocity; thereby, improving plant water conservation during photosynthesis (Schymanski and Or, 2016).

T-air is an important environmental factor that controls the growth of plants. The increase in shades at the agroforestry phase highly reduced the signalgrass production. Optimum tair for the growth of signalgrass ranged from 30-35 ㄷ (FAO, 2016), while average Tair at the study site was 25.89 ․ C. It is less optimal for the growth of signalgrass. Tair affected almost all plants during physiological process, from phenotypic development to catalyzed reaction on enzymatic basis and the transportation of cell membranes for physical processes, such as transpiration, respiration, and volatilization of specific compounds (Mondal et al., 2016).

The environmental assessment results indicated that signalgrass production can be increased by adding organic matters in soil and pruning management. Organic fertilizer application can restore damaged natural fertility of soil and improve plant productivity. Organic fertilizer improves natural soil process thereby giving a long term effect on soil fertility (Singh, 2012). Utamy et al. (2018) informed that manure application improves physical and chemical properties of the soil and napiergrass productivity and Italian ryegrass in Hilly Southern Kyushu, Japan.

The increase in $\mathrm{U}_{2}$ and Tair among the stands can be made by routine annual pruning. Annual pruning was required for sustainable production (Retamales and Hancock, 2012). Prunning at the intermediate and advanced phases can reduce shades, which consequently, can improve macro and micro climates among the stands and air temperature and wind velocity; thereby, improving the yields of signalgrass production (Bosi, 2017).

Proper pruning was essential for optimizing the relation between shoots growth, leaf areas, photosynthesis, storage reserves, and final understanding of high yields with good quality fruits (Demirtas et al., 2010). If no pruning is performed, shoots become shorter and thinner and complex canopies are formed and total plant growth and volume reduced (Müller, 2011).

\section{Materials and Methods}

\section{Study site}

The survey-based study was conducted during dry and wet seasons in 2017-2018. Sampling of dry season was conducted in May-October, while for wet season sampling was dome in November-April, in Merapi Mounth in Cangkringan District, Sleman Regency, Special Province of Yogyakarta, Indonesia. The study site was selected because the site represented the condition of mountain ecosystems in general. The survey-based study was located $\pm 24 \mathrm{~km}$ to the north-east of the downtown of Yogyakarta City, Indonesia (Fig 3).

\section{Soil sampling and analysis}

The physical, chemical and biological properties of the soil were measured. Observations were conducted at the General Soil and Microbiology Laboratory, Faculty of Agriculture, Universitas Gadjah Mada, Yogyakarta, Indonesia. Soil sampling was conducted in 27 locations with random sampling methods at a depth of $0-30 \mathrm{cms}$ (Alam, 2014). Soil sampling was conducted at each agroforestry phase (initial, intermediate, and advanced phases) at the beginning of the dry and wet seasons in 2017 and 2018. Soil quality observation covered physical, chemical and biological properties of the soil (Table 3).

\section{Macro and microclimate variables}

Macro and microclimate observations on site were Tair, Tsoil, $\mathrm{RH}, \mathrm{U}_{2}$, and Rs. The observations were conducted on 
site (Alam, 2014). Macro and micro climate observations were conducted once a week on random basis at each agroforestry phase (initial, intermediate, and advanced phases) in dry and wet seasons in 2017 and 2018. The observations were conducted in 27 sampling locations.

\section{Signalgrass variables}

Signalgrass production so observed were dry weight shoots per hectare. Field data collection was made on random basis by using quadratic method approach. Sample ring size was 2 $x 2$ namely 3 samples per location (Alam, 2014). Observation was conducted at the end of dry and wet seasons in 2017 and 2018 . Signalgrass was exposed to $11 \%$ of sunlight at the moisture level.

\section{Statistical approach}

This study used stratified random sampling methods. Stratification is based on site (agroforestry phase) and environment (season and year). Site nested on environment. Agroforestry phase consisted of initial phase $(<50 \%$ of the shade intensity of the sun), intermediate phase $(50-70 \%$ of the shade intensity of the sun), and advanced phase (>70\% of the shade intensity of the sun). Seasons divided into dry season (rainfall $<60 \mathrm{~mm} \cdot \mathrm{month}^{-1}$ ) and wet season (rainfall > $100 \mathrm{~mm} \cdot \mathrm{month}^{-1}$ ). Years consisted of 2017 and 2018.

Signalgrass production was analyzed with linear mixed models. The models were evaluated for assumptions. Normality tests were conducted by using the Kolmogorov test and Q-Q plot (Mocada et al., 2014). The general form of the linear mixed models used in this study was as follows:

$\mathrm{y}=\mathrm{X} \beta+\mathrm{Zu}+\mathrm{e}$

Where; $y$ is vector of signal grass productivity observation, $\beta$ is vector of permanent effect with incidence matrix $X, u$ is vector of random effect with incidence matrix $Z$, and e is residual vector. We assumed that the agroforestry phase $\left(\alpha_{i}\right)$ is a permanent effect. Therefore, permanent effect X $\beta$ is:

$\mu+\alpha_{i}$

Seasons and years were combined as a single factor called period $p_{j}$ because wet and dry seasons from one year to another year were considered different, and the effect of this period factor was random. Therefore, the interaction effect at the agroforestry phase and in the periods was random. The site at each agroforestry phase $s_{k(i)}$ was also considered as a random effect. Therefore, the random effect $\mathrm{Zu}$ is:

$s_{k(i)}+p_{j}+\alpha p_{i j}$

Residual variance was modelled as heterogeneous specificenvironment $R=\bigoplus_{j=1}^{J} R_{j}$, where $R_{j}$ is a diagonal matrix with diagonal element $\sigma_{\varepsilon(j)}^{2}$. The LSD Fisher with $\alpha=0.05$ was used as a post hoc analysis of permanent effect.

The approach used Analysis of Variance (ANOVA) $\alpha=5 \%$ to test the soil quality and climate parameters in the different agroforestry phase (Suryanto et al., 2017). Only the soil quality and climate parameters showed significant treatment differences $(p<0.05)$ and had variance coefficient of $<40 \%$ chosen for the Structural Equation Modelling (SEM) (Suryanto et al., 2017).

Furthermore, SEM screening also conducted stepwise regression analysis on soil quality and climate parameters (Smith et al., 1993). Linear mixed model and stepwise regression analysis was conducted by using statistical analysis software (SAS) software (version 9.4 for Windows; SAS Institute Inc., Cary, NC, USA) (SAS Institute, 2013). Statistical analysis was conducted with PROC MIXED, PROC GLM, and PROC REG. The graphic was made in RStudio (RStudio Team, 2015) using ggplot2 (Wickham, 2009). The SEM was conducted by using Smart PLS 3 software (Fernandes, 2008; Ghozali, 2008).

\section{Conclusion}

The study results indicate that the highest signalgrass production at the initial agroforestry phase was 4.50 tons.ha 1. There is a very significant decrease in signalgrass production at the intermediate agroforestry phase by 36.64 $\%$ at the advanced agroforestry phase by $280.80 \%$ compared to the initial agroforestry phase. The signalgrass production was increased very significantly by the increase in CEC, SOC, $\mathrm{T}$-air, and $\mathrm{U}_{2}$. In addition, it was also significantly influenced by $\mathrm{NO}_{3}^{-}$. Signalgrass production can be improved by the assessment tools by improving $\mathrm{CEC}, \mathrm{NO}_{3}{ }^{-}, \mathrm{SOC}, \mathrm{U}_{2}$, and T-air with routine organic matters application and annual pruning.

\section{Acknowledgment}

The authors would like to express their profuse thanks to Universitas Gadjah Mada which has funded this research through the University grant-in-aid scheme (No: 2431/UN1.P.III/DIT-LIT/LT/2017). Our special thanks go to Mr. Harimurti Buntaran (Doctoral Student at the Swedish University of Agricultural Sciences, Sweden and Universitat Hohenheim, Germany), for his assistance in data analysis.

\section{References}

Alam T (2014) Optimization management of clove, cacao and cardamom agroforestry system in Menoreh Mountain Area. M.Sc. Thesis. Faculty of Agriculture, Universitas Gadjah Mada, Yogyakarta, Indonesia.

Alavalapati JRR, Nair PKR (2001) Socio-economic and institutional perspectives of agroforestry. In: Palo $M$, Uusivuori J (ed) World forests, society and environment markets and policies. Kluwer Academic Publishers, Dordrecht. 52-62.

Aubert G, Ollat C, Pinta M (1954) Analytical methods currently used at IDERT soil laboratories. In: Proceedings of the international conference of African soil. Leopoldville. 1267-1276.

Bauer A, Velde BD (2014) Geochemistry at the earth's surface. Springer-Verlag, Berlin, Heidelberg.

Beck H, Zimmermann NE, Mcvicar T, Vergopolan N (2018) Present and future Köppen-Geiger climate classification maps at 1-km resolution. Sci Dat. 5(180214).

Bilgili AV, Kucuk C, van Es HM (2017) Assessment of the quality of the Harran Plain soils under long-term cultivation. Environ Monit Assess. 189:460.

Black CA (1965) Methods of soil analysis part 2. American Society of Agronomy, Madison, Wisconsin, USA.

Blake GR, Hartge KH (1986) Methods of soil analysis part I: Physical and mineralogical methods. In: Klute A (ed) Bulk density. American Society of Agronomy, Madison, USA. 363-375.

Bosi C (2017) Parameterization and evaluation of mechanistic crop model for estimating Urochloa brizantha cv. bps plata productivity under full sun and in 
silvopasturel system. Ph.D. Thesis. Luiz de Queiroz Collage of Agriculture, University of Sao Paulo, Brazil.

Boudsocq S, Niboyet A, Lata JC, Raynaud X, Loeuille N, Mathieu J, Blouin M, Abbadie L, Barot S (2012) Plant preference for ammonium versus nitrate: A neglected determinant of ecosystem functioning?. Am Nat. 180:6069.

Brady MV, Hedlund K, Cong RG, Hemerik L, Hotes S, Machado S, Mattsson L, Schulz E, Thomsen IK (2015) Valuing supporting soil ecosystem services in agriculture: $\mathrm{A}$ natural capital approach. Agron J. 107:1809.

Brady NC, Weil RR (2008) Soil colloids: Seat of soil chemical and physical acidity. In: Brady NC, Weil RR (ed) The nature and properties of soils. Pearson Education Inc. Upper Saddle River, NJ, USA. 311-358.

Brandão M, Canals LMI (2013) Global characterisation factors to assess land use impacts on biotic production. Int J Life Cycle Assess. 18:1243-1252.

Burt M (2004) Soil survey laboratory methods manual. In: Soil survey investigations report no. 42 version 4.0. Natural Resources Conservation Service, United States Department of Agriculture, USA.

Cazetta JO, Villela LCV (2004) Nitrate reductase activity in leaves and stems of tanner grass (Brachiaria radicans Napper). Sci Agric. 61(6):640-648.

Chester CC, Hilty JA, Hamilton LS (2013) Mountain gloom and mountain glory revisited: A survey of conservation, connectivity, and climate change in mountain regions. J Mount Ecol. 9:1-34.

Chung ELT, Predith M, Nobilly F, Samsudin AA, Jesse FFA, Loh TC (2018) Can treatment of Brachiaria decumbens (signal grass) improve its utilisation in the diet in small ruminants?-a review. Trop Anim Health Prod. 50(8):17271732.

Clason TR, Sharrow SH (2000) Silvopasture practices. In: Garrett HE, Rietveld WJ, Fisher RF (ed) North American agroforestry: An integrated science and practice. American Society of Agronomy, Madison, WI. 119-147.

Cobb JN, DeClerck G, Greenberg A, Clark R, McCouch S (2013) Next-generation phenotyping: Requirements and strategies for enhancing our understanding of genotypephenotype relationships and its relevance to crop improvement. Theor App Gen. 126:867-887.

David AB, Davidson CE (2014) Estimation method for serial dilution experiments. J Microbiol Met. 107:214-221.

Demirtas MN, Bolat, Ercisli L, Holmez OOIA, Altindag SM, Celik B (2010) The effects of different pruning treatments on seasonal variation of carbohydrates in 'hacihaliloglu' apricot cultivar. Not Bot Horti Agrobot Cluj-Napoca. 38:223-227.

Dinpashoh $Y$, Jhajharia D, Fakheri FA, Singh VP, Kahya E (2011) Trends in reference crop evapotranspiration over Iran. J Hydrol. 399:422-433.

Dwidjopuspito, T (1986) Soil moisture prediction. Ph.D. Thesis. University of The Philippines, Los Banos, Philippines.

FAO (2016) Grassland index: A searchable catalogue of grass and forage legumes. FAO, Rome, Italy.

Fernandes AAR (2008) Structural equation modeling approach pls and sem: Application of smart pls and amos software. Laboratory of Statistics Faculty of Mathematics and Natural Sciences Brawijaya University, Malang, Indonesia.
Garrett HE, Rietveld WJ, Fisher RF (2000) North American agroforestry: An integrated science and practice. American Society of Agronomy, Madison, WI.

Gertisser R, Charbonnier SJ, Keller J, Quidelleur X (2012) The geological evolution of Merapi volcano, Central Java, Indonesia. Bull Volcanol. 74:1213-1233

Ghozali I (2008) Structural equation modeling: Alternative method with partial least square (pls), 2nd edn, Diponegoro University, Semarang, Indonesia.

Glover JD, Reganold JP, Andrews PK (2000) Systematic method for rating soil quality of conventional, organic, and integrated apple orchards in Washington State. Agric Ecosyst Environ. 80:29-45.

Hajek BF, Adams F, Cope jr JT (1972) Rapid determination of exchangeable bases, acidity and base saturation for soil characterization. Soil Sci Soc Am J. 36:436-438.

Hazelton PA, Murphy BW (2007) Interpreting soil test results: What do all the numbers mean?. CSIRO Publishing, Melbourne.

Jones (1984) Laboratory guide of exercises in conducting soil test and plant analysis. Benton Laboratories Inc. USA.

Khalil HPSA, Hossain MS, Rosamah E, Azli NA, Saddon N, Davoudpoura $Y$, Islam MN, Dungani R (2015) The role of soil properties and it's interaction towards quality plant fiber: A review. Renew Sustain Ener Rev. 43:1006-1015.

Kurtz WB (2000) Economics and policy of agroforestry. In: Garrett HE, Rietveld, WJ, Fisher RF (ed) North American agroforestry: An integrated science and practice. American Society of Agronomy, Madison, WI. 321-360.

Low SG (2015) Signal Grass (Brachiaria decumbens) toxicity in grazing ruminants. Agric. 5:971-990.

Makalew AM (2011) Determination of minimum data set (mds) and soil quality index base on sustainable land management, Ph.D. Thesis. Faculty of Agriculture, Universitas Gadjah Mada, Yogyakarta.

McGrath D, Zhang CS (2003) Spatial distribution of soil organic carbon concentrations in grassland of Ireland. App Geochem. 18:1629-1639.

McVicar TR, Roderick ML, Donohue RJ, Li LT, Van Niel TG, Thomas A, Grieser J, Deepak J, Himri Y, Mahowald NM, Mescherskaya AV, Andries CK, Rehman S, Dinpashoh Y (2012) Global review and synthesis of trends in observed terrestrial near-surface wind speeds: Implications for evaporation. J Hydrol. 416:182-205.

Mocanda MP, Gabriels D \& Cornelis WM (2014) Data-driven analysis of soil quality parameters using limited data. Geoderma, 235-236:271-278.

Mondal S, Ghosal S, Barua R (2016) Impact of elevated soil and air temperature on plants growth, yield and physiological interaction: A critical review. Sci Agri. 14(3):293-305.

Müller JL (2011) Pruning and pollination studies on southern highbush blueberries. M.Sc. Thesis. University of Stellenbosch, Stellenbosch, South Africa.

Neenu S, Biswas AK, Rao AS (2013) Impact of climatic factors on crop production - a review. Agri Rev. 34(2):97-106.

Olsen SR, Cole CV, Watanabe FS, Dean LA (1954) Estimation of available phosphorus in soils by extraction with sodium bicarbonate. United States Department of Agriculture, Washington, USA.

Qi YB, Darilek JL, Huang B, Zhao YC, Sun WX, Gu ZQ (2009) Evaluating soil quality indices in an agricultural region of Jiangsu Province, China. Geoderma. 149:325-334. 
Retamales JB, Hancock JF (2012) Blueberries. CABI Publishing, Wallingford, UK. 172-177.

Richards LA (1954) Diagnosis and improvement of saline and alkali soils. U.S. Salinity Laboratory Staff, Departement of Agriculture, Washington, USA.

Rossi JP, Franc A, Rousseau GX (2009) Indicating soil quality and the GISQ. Soil Biol Biochem. 41:444-445.

Rousseau GX, Deheuvels O, Arias IR, Somarriba E (2012) Indicating soil quality in cacao-based agroforestry system and old-growth forests: The potential of soil macrofauna assemblage. Ecol Indicat. 23:535-543.

RStudio Team (2015). RStudio: Integrated development for R. RStudio, Inc., Boston, MA.

SAS Institute (2013) Base SAS ${ }^{\circ}$ 9.4. Procedures guide: Statistical procedures, 2nd edn., SAS Institute Inc, Cary, NC, USA.

Schymanski SJ, Or D (2016) Wind increases leaf water use efficiency. J Plant Cell Environ. 39(7).

Singh RP (2012) Organic fertilizers: Types, production and environmental Impact. Nova Science Inc., New York, USA.

Smith JL, Halvorson JJ, Papendick RI (1993) Using multiplevariable indicator kriging for evaluating soil quality. Soil Sci Soc Am J. 57:743-749.

Soil Survey Staff (2014) Key to soil taxonomy. United States Department of Agriculture Natural Resources Conservation Service, USA.
Stenholm A, Holmstrom S, Ragnarsson A (2009) Total nitrogen in waste water analysis: Comparison of devarda's alloy method and high temperature oxidation followed by chemiluminescence detection. J Anal Chem. 64:1047-1053.

Suryanto P, Tohari, Putra ETS, Alam T (2017) Soil quality assessment for yield improvement of clove, cacao and cardamom agro-forestry system in Menoreh mountains area, Indonesia. J Agron. 16:160-167.

Suryanto P, Zaki MH, Azmy M, Azani MA (2011) Silviculture agroforestry regime: Compatible management in southern Gunung Merapi National Park, Java, Indonesia. Inter J Biol. 3(2):115-126.

Timsina J (2018) Can organic sources of nutrients increase crop yields to meet global food demand?. Agron. 8(214).

Utamy RF, Ishii Y, Idota S, Khairani L (2018) Effect of repeated application of manure on herbage yield, quality and wintering ability during cropping of dwarf napiergrass with italian ryegrass in Hilly Southern Kyushu, Japan. Agron. 8(30).

Van Reeuwijk LP (1993) Procedures for soil analysis. International Soil Reference and Information Centre, Wageningen, Netherlands.

Wickham H (2009) Ggplot2: Elegant graphics for data analysis. Springer, New York. 